\title{
Synthesis of New Imidazolidine and Tetrahydropyrimidine Derivatives
}

\author{
Hamid Beyzaei, Reza Aryan, and Zahra Keshtegar \\ Department of Chemistry, Faculty of Science, University of Zabol, Zabol 9861335856, Iran \\ Correspondence should be addressed to Hamid Beyzaei; hbeyzaei@yahoo.com
}

Received 4 May 2014; Accepted 23 June 2014; Published 14 July 2014

Academic Editor: Hideaki Shirota

Copyright ( 2014 Hamid Beyzaei et al. This is an open access article distributed under the Creative Commons Attribution License, which permits unrestricted use, distribution, and reproduction in any medium, provided the original work is properly cited.

\begin{abstract}
Synthesis of new imidazolidine and tetrahydropyrimidine derivatives $\mathbf{3} \mathbf{a}, \mathbf{b}$ and $\mathbf{4 a - c}$ as cyclic 1,3 -diamines under two reaction conditions ( $\mathrm{A}$ and $\mathrm{B}$ ) is described. Under reaction conditions-A, a suspension of $(E)$-2-cyano-2-(oxazolidin-2-ylidene)ethanethioamide $\mathbf{1}$ (1 eq.) and diaminoalkanes $\mathbf{2 a - e}$ (2 eq.) in absolute ethanol is heated under reflux for 16-22 h to afford $\mathbf{3 a}$, b and $\mathbf{4 a} \mathbf{a}-\mathbf{c}$. Alternatively, under reaction conditions- $\mathrm{B}$, a solution of thioamide $\mathbf{1}$ (1 eq.) in diaminoalkanes $\mathbf{2 a - e}$ ( 3 eq.) is stirred under solvent-free conditions at room temperature for 3 days to give desired products. Reaction conditions-A for having higher yields, shorter reaction times, and required less diamines is more effective than reaction conditions-B. Oxazolidine ring opening is observed by reacting compound 1 with all of the diamines $\mathbf{2 a}-\mathbf{e}$, but the thioamide group only reacts with nonbulky diamines $\mathbf{2 a}, \mathbf{b}$. The chemical structures of novel compounds were confirmed by ${ }^{1} \mathrm{H}$ NMR, ${ }^{13} \mathrm{C}$ NMR, elemental analysis, and FT-IR spectrometry.
\end{abstract}

\section{Introduction}

Imidazolidines (tetrahydroimidazoles) are important building blocks in biologically active compounds [1] and carriers of pharmacologically active carbonyl compounds [2]. They have been reported to have important biological activities including, for example, 2-[(arylmethoxy) imino]imidazolidines as potential $\alpha$-adrenergic receptor agonist [3], bisimidazolidines and 1,3-disubstituted imidazolidines as antimicrobial [4], 5-(4-chloro or fluoro-benzylidene-3-(4nitrebenzyl)-4-thioxo-imidazolidin-2-one as antiparasitic [5], sulfonyliminoimidazolidines as oral hypoglycaemic [6], imidazolidin-2,4-diones, 2-thioxoimidazolidin-4-ones, 5-cycloalkylidene-hydantoins, and 5-cycloalkylidene-thiohydantoins as antiarrhythmic and anticonvulsant $[7,8]$, 1,3-dibenzyl-2-arylimidazolidine as anti-inflammatory [9], $N, N^{\prime}$-di-aryl-methyl-2-(4-diethylamino phenyl) tetrahydroimidazoles and $N, N^{\prime}$-di-4-diethylamino benzyl-2-(aryl) tetrahydroimidazoles as analgesic [10]. They have also been utilized as a versatile template for the synthesis of compounds with potential cyclooxygenase-2 inhibition activity [11] and termed as a promising group of NSAIDs with potential anti-inflammatory activities [9].
The pyrimidine fragment is present in various biologically active compounds, many of which have been found to be used in medical practice $[12,13]$. Recently, much attention has been paid to derivatives of pyrimidine, including their hydrogenation products. This class of compounds displays wide ranges of biological and pharmacological properties such as anti-inflammatory [14], analgesic [15], antitumor [16], antidepressant [17], antibacterial, antifungal, and antitubercular effects [18-20].

The application of these compounds in pharmaceutical field prompted us to synthesize some new imidazolidines and tetrahydropyrimidines under two reaction conditions. These synthesized compounds are characterized by NMR, IR spectral data, and elemental analysis.

\section{Results and Discussion}

Cyclic 1,3-diamines 3a, $\mathbf{b}$ and $\mathbf{4 a - c}$ were prepared under two reaction conditions. Under reaction conditions-A, a mixture of (E)-2-cyano-2-(oxazolidin-2-ylidene)ethanethioamide $\mathbf{1}$ (1 eq.) and appropriate diaminoalkanes $\mathbf{2 a - e}$ (2 eq.) in absolute ethanol are refluxed for $16-22 \mathrm{~h}$ to afford the solid products $\mathbf{3 a}, \mathbf{b}$ and $\mathbf{4 a - c}$ (Scheme 1). Under reaction conditions-B, 


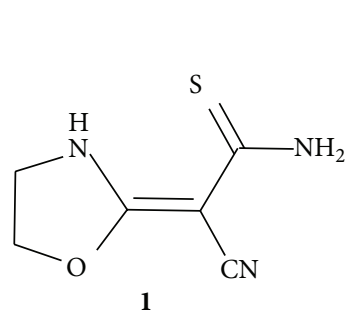

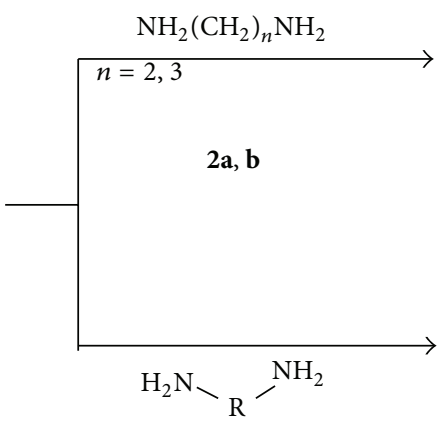

$2 \mathrm{c}-\mathrm{e}$

$$
\text { 3a: } n=2 \quad \mathrm{R}=
$$

3b: $n=3$

(c)

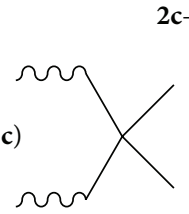

(d)

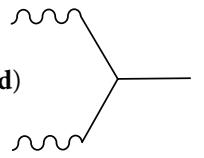<smiles>N#CC(=C1N=CN1)c1no[nH]1</smiles>

$3 a, b$<smiles>N#CC(C(N)=S)=c1[nH][R][nH]1</smiles>

$4 a-c$

(e)<smiles>OCC1CCCCC1[Al]</smiles>

Scheme 1: Total synthesis of cyclic 1,3-diamines $\mathbf{3 a}, \mathbf{b}$ and $\mathbf{4 a - c}$.

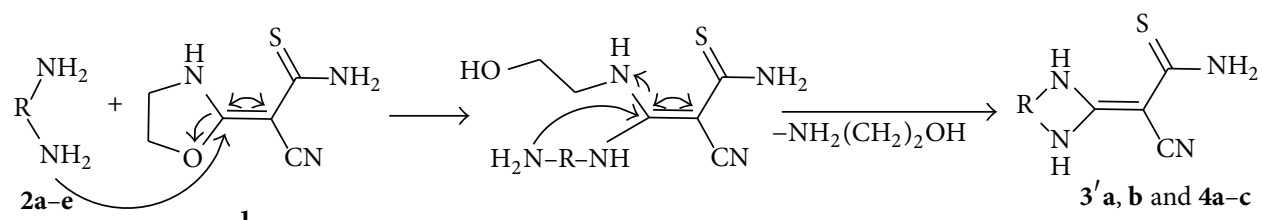

1<smiles>N#C/C(C(N)=S)=C1/NC=[NH+]1</smiles>

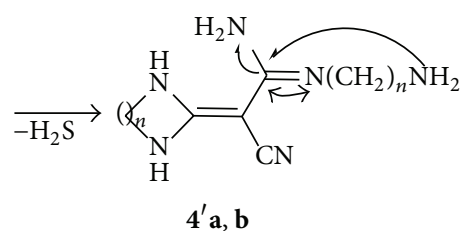<smiles>N#CC(=C1NC(CN)N1)c1no[nH]1</smiles>

SCHEME 2: The proposed mechanism of formation $\mathbf{3 a}, \mathbf{b}$ and $\mathbf{4 a - c .}$

similar treatment of the thioamide $\mathbf{1}$ (1 eq.) with appropriate diaminoalkanes $\mathbf{2 a - e}$ (3 eq.) under solvent-free conditions at room temperature for 3 days afforded the desired products. The yields of the products obtained are depicted in Table 1.

A comparison between the results obtained from both reaction conditions leads us to the conclusion that reaction conditions-A is from $65 \%$ to $77 \%$ as efficient as reaction conditions- $\mathrm{B}$, also the former has shorter reaction times and required less diamines but requires a supply of heat. It is worth noting that oxazolidine ring opening is observed by reacting compound $\mathbf{1}$ with all of the diamines $\mathbf{2 a - e}$, but the thioamide group only reacts with nonbulky diamines $\mathbf{2 a}, \mathbf{b}$. This is probably due to the rigid structure of compound $\mathbf{1}$ that prevents the effective interaction with bulky diamines $\mathbf{2 c - e}$.

A plausible mechanism is depicted for the formation of these compounds (Scheme 2). As depicted in Scheme 2, intermediates $\mathbf{3}^{\prime} \mathbf{a}, \mathbf{b}$ and $\mathbf{4} \mathbf{a}-\mathbf{c}$ probably were produced from two successive Michael substitution reaction thioamide $\mathbf{1}$ and diaminoalkanes $\mathbf{2 a - e}$. It predicts that during adding amine to oxazolidine ring, the $\mathrm{C}-\mathrm{O}$ bond breaks faster than the $\mathrm{C}-$ $\mathrm{N}$ bond because alkoxy is a better leaving group than amine. Note that in this multistep synthesis, the likely key intermediates $\mathbf{3}^{\prime} \mathbf{a}, \mathbf{b}$ were not isolated except for intermediates 4a-c which were isolated and their structures identified by spectral analysis. When intermediates $\mathbf{3}^{\prime} \mathbf{a}, \mathbf{b}$ were treated with diaminoalkanes $2 \mathbf{a}, \mathbf{b}$, amidines $4^{\prime} \mathbf{a}, \mathbf{b}$ that are produced as intermediates followed by a ring closure to $\mathbf{3} \mathbf{a}, \mathbf{b}$.

The structural assignments of compounds $\mathbf{3 a}, \mathbf{b}$ and $\mathbf{4 a - c}$ were based on their analytical and spectral data. The ${ }^{1} \mathrm{H}$ NMR spectra of compounds $3 \mathbf{a}-\mathbf{e}$ showed broad signals due to -NH- groups within $\delta=7.70-9.51 \mathrm{ppm}$ region. The ${ }^{13} \mathrm{C} \mathrm{NMR}$ spectra of the products exhibited signals within $\delta=27-65$, $117-119,157-166 \mathrm{ppm}$ regions attributed to the $\mathrm{N} \equiv \mathrm{C}-\mathrm{C}=\mathrm{C}-$, $-\mathrm{C} \equiv \mathrm{N}, \mathrm{N} \equiv \mathrm{C}-\mathrm{C}=\mathrm{C}-$ carbons, respectively. The FT-IR spectra of $\mathbf{3 a}, \mathbf{b}$ and $\mathbf{4 a}-\mathbf{c}$ in $\mathrm{KBr}$ disk showed the absorption bands within $v=3273-3311 \mathrm{~cm}^{-1}$ corresponding to $-\mathrm{NH}$ - groups, within $v=2170-2187 \mathrm{~cm}^{-1}$ belonging to nitrile groups and within $\nu=1589-1688 \mathrm{~cm}^{-1}$ attributed to the $-\mathrm{C}=\mathrm{C}-$ exocyclic 
TABLE 1: Comparing yields of compounds $\mathbf{3 a}, \mathbf{b}$ and $\mathbf{4 a} \mathbf{a}-\mathbf{c}$ obtained under two reaction conditions $\mathrm{A}$ and $\mathrm{B}$.

\begin{tabular}{|c|c|c|c|c|c|}
\hline \multirow{2}{*}{ Entry } & \multirow{2}{*}{ Products } & \multirow{2}{*}{ Diaminoalkane } & \multirow{2}{*}{ Time $(\mathrm{h})^{\mathrm{a}}$} & \multicolumn{2}{|c|}{ Yield (\%) } \\
\hline & & & & A & $\mathrm{B}$ \\
\hline 1 & $3 \mathbf{a}$ & Ethylenediamine & 16 & 75 & 47 \\
\hline 2 & $3 b$ & 1,3-Diaminopropane & 16 & 60 & 46 \\
\hline 3 & $4 a$ & 2,2-Dimethyl-1,3-propanediamine & 20 & 77 & 50 \\
\hline 4 & $4 b$ & 1,2-Diaminopropane & 18 & 56 & 44 \\
\hline 5 & $4 c$ & 1,2-Diaminocyclohexan & 22 & 54 & 42 \\
\hline
\end{tabular}

${ }^{a}$ Only for reaction conditions-A.

bonds. All this evidence plus microanalytical data strongly supports the formation of all products.

\section{Materials and Methods}

3.1. Materials. Melting points were recorded on a Kruss type KSP1N melting point meter and are uncorrected. The IR spectra of products $3 \mathbf{a}, \mathbf{b}$ and $\mathbf{4 a}-\mathbf{c}$ were determined using $\mathrm{KBr}$ disks with Bruker Tensor-27 FT-IR spectrometer and only major absorptions are listed. The ${ }^{1} \mathrm{H}$ and ${ }^{13} \mathrm{C}$ NMR spectra of DMSO- $\mathrm{d}_{6}$ solutions were recorded on a Bruker FT-NMR Ultra Shield-400 spectrometer $(400$ and $100 \mathrm{MHz}$, resp.) with residual protons of the solvent as internal standard (2.50 ppm for ${ }^{1} \mathrm{H}$ and $39.48 \mathrm{ppm}$ for ${ }^{13} \mathrm{C}$ ). Elemental analyses were performed on a Thermo Finnigan Flash EA microanalyzer. Monitoring of the progress of reactions and the purity of the products were effected by TLC on alufoil plates precoated with silica gel (60, Merck); eluent was $\mathrm{CHCl}_{3}$ $\mathrm{CH}_{3} \mathrm{OH}, 9: 1$, visualization with $\mathrm{I}_{2}$ vapor. Compound 1 was obtained according to the published method [21].

\subsection{Methods}

3.2.1. General Procedure for the Synthesis of Cyclic 1,3-diamines $(3 \boldsymbol{a}, \boldsymbol{b}$ and $4 \boldsymbol{a}-\boldsymbol{c})$. Reaction conditions-A. A suspension of (E)-2-cyano-2-(oxazolidin-2-ylidene)ethanethioamide $\mathbf{1}$ $(0.845 \mathrm{~g}, 5 \mathrm{mmol})$ and diaminoalkanes $\mathbf{2 a}-\mathbf{e}(10 \mathrm{mmol})$ in absolute ethanol $(10 \mathrm{~mL})$ is heated under reflux for $16-22 \mathrm{~h}$. The reaction mixture is treated with 2-propanol $(10 \mathrm{~mL})$, refrigerated overnight, filtered, and washed with 2-propanol; the residual products are recrystallized from methanol to give $3 a, b$ and $4 a-c$.

Reaction conditions-B. A solution of (E)-2-cyano-2(oxazolidin-2-ylidene)ethanethioamide $\mathbf{1}(0.845 \mathrm{~g}, 5 \mathrm{mmol})$ in diaminoalkanes $\mathbf{2 a - e}(15 \mathrm{mmol})$ is stirred at room temperature for 3 days. Excess diamines are then evaporated in vacuo and the residual products are recrystallized from methanol.

\section{Data for Compounds}

2-(4,5-Dihydro-1H-imidazol-2-yl)-2-(imidazolidin-2-

ylidene)acetonitrile $3 \boldsymbol{a}$. White needles, $\mathrm{mp} 218-219^{\circ} \mathrm{C}$; FT-IR, $v, \mathrm{~cm}^{-1}$ : 3280 (broad, medium, -NH-), 2170 (strong, sharp, $-\mathrm{C} \equiv \mathrm{N}$ ), and 1688 (strong, sharp, $-\mathrm{C}=\mathrm{C}-$ ); ${ }^{1} \mathrm{H}$ NMR, $\delta$, ppm: $3.55\left(\mathrm{~s}, 8 \mathrm{H},-\mathrm{CH}_{2}-\right) ; 8.21\left(\mathrm{~b}, 3 \mathrm{H},-\mathrm{NH}-, \mathrm{D}_{2} \mathrm{O}\right.$ exchangeable); ${ }^{13} \mathrm{C}$ NMR, $\delta$, ppm: $27.8(\mathrm{~N} \equiv \mathrm{C}-\mathrm{C}=\mathrm{C}-), 43.7$
$\left(-\mathrm{CH}_{2}-\right)$, $117.8(-\mathrm{C} \equiv \mathrm{N})$, and $166.5(\mathrm{~N} \equiv \mathrm{C}-\mathrm{C}=\mathrm{C}-)$. Anal. Calcd. for $\mathrm{C}_{8} \mathrm{H}_{11} \mathrm{~N}_{5}$ (177) C 54.22; H 6.26; N 39.52\%, Found: C 54.11; H 6.34; N 39.55 .

2-(Tetrahydropyrimidin-2(1H)-ylidene)-2-(1,4,5,6-tetrahydropyrimidin-2-yl)acetonitrile $3 \boldsymbol{b}$. White needles, $\mathrm{mp} 209-210^{\circ} \mathrm{C}$; FT-IR, $v, \mathrm{~cm}^{-1}: 3286$ (broad, medium, $-\mathrm{NH}-$ ), 2171 (strong, sharp, $-\mathrm{C} \equiv \mathrm{N}$ ), and 1688 (strong, sharp, $-\mathrm{C}=\mathrm{C}-$ ); ${ }^{1} \mathrm{H}$ NMR, $\delta, \operatorname{ppm}(J, \mathrm{~Hz}): 1.77\left(\mathrm{q}, 4 \mathrm{H}, J=5.5,-\mathrm{NHCH}_{2} \mathrm{CH}_{2}-\right), 3.18$ (t, $8 \mathrm{H}, J=5.5,-\mathrm{NHCH}_{2}-$ ), and $7.70\left(\mathrm{~b}, 3 \mathrm{H},-\mathrm{NH}-, \mathrm{D}_{2} \mathrm{O}\right.$ exchangeable); ${ }^{13} \mathrm{C}$ NMR, $\delta$, ppm: $19.6\left(-\mathrm{NHCH}_{2} \mathrm{CH}_{2}-\right)$, $29.2(\mathrm{~N} \equiv \mathrm{C}-\mathrm{C}=\mathrm{C}-), 38.6\left(-\mathrm{NHCH}_{2}\right)$, and $118.7(-\mathrm{C} \equiv \mathrm{N}) ; 159.3$ $(\mathrm{N} \equiv \mathrm{C}-\mathrm{C}=\mathrm{C}-)$. Anal. Calcd. for $\mathrm{C}_{10} \mathrm{H}_{15} \mathrm{~N}_{5}$ (205) C 58.51; $\mathrm{H}$ 7.37; N 34.12\%, Found: C 58.53; H 7.27; N 34.20.

2-Cyano-2-(5,5-dimethyltetrahydropyrimidin-2(1H)-ylidene) ethanethioamide $\mathbf{4 a}$. White needles, $\mathrm{mp} 216-218^{\circ} \mathrm{C}$; FT-IR, $v$, $\mathrm{cm}^{-1}$ : 3416 (broad, medium, $-\mathrm{NH}_{2}$ ), 3311 (broad, medium, $-\mathrm{NH}-$ ), 2175 (strong, sharp, $-\mathrm{C} \equiv \mathrm{N}$ ), and 1615 (strong, sharp, $-\mathrm{C}=\mathrm{C}-$ ); ${ }^{1} \mathrm{H}$ NMR, $\delta, \mathrm{ppm}(\mathrm{J}, \mathrm{Hz}): 0.95$ (s, $6 \mathrm{H},-\mathrm{CH}_{3}$ ), $3.00\left(\mathrm{~d}, 4 \mathrm{H}, J=2.2,-\mathrm{CH}_{2}-\right), 7.27\left(\mathrm{~b}, 2 \mathrm{H},-\mathrm{NH}_{2}, \mathrm{D}_{2} \mathrm{O}\right.$ exchangeable), and $9.51\left(\mathrm{~b}, 2 \mathrm{H},-\mathrm{NH}-, \mathrm{D}_{2} \mathrm{O}\right.$ exchangeable); ${ }^{13} \mathrm{C}$ NMR, $\delta$, ppm: $23.5\left(-\mathrm{CH}_{3}\right), 25.0\left(-\mathrm{C}\left(\mathrm{CH}_{3}\right)_{2}-\right), 49.2$ $\left(-\mathrm{CH}_{2}-\right), 65.0(\mathrm{~N} \equiv \mathrm{C}-\mathrm{C}=\mathrm{C}-), 119.4(-\mathrm{C} \equiv \mathrm{N}), 157.1 \quad(\mathrm{~N} \equiv \mathrm{C}-$ $\mathrm{C}=\mathrm{C}-)$, and $186.7(-\mathrm{C}=\mathrm{S})$. Anal. Calcd. for $\mathrm{C}_{9} \mathrm{H}_{14} \mathrm{~N}_{4} \mathrm{~S}(210)$ C 51.40; H 6.71; N 26.64; S 15.24\%, Found: C 51.35; H 6.78; N 26.72; S 15.15 .

(Z,E)-2-Cyano-2-(4-methylimidazolidin-2-ylidene)ethanethioamide $\mathbf{4} \boldsymbol{b}$. Yellow needles, $\mathrm{mp} 189-190^{\circ} \mathrm{C}$; FT-IR, $\nu, \mathrm{cm}^{-1}$ : 3422 (broad, medium, $-\mathrm{NH}_{2}$ ), 3282 (broad, medium, $-\mathrm{NH}-$ ), 2182 (strong, sharp, $-\mathrm{C} \equiv \mathrm{N}$ ), and 1626 (strong, sharp, $-\mathrm{C}=\mathrm{C}-$ ); ${ }^{1} \mathrm{H}$ NMR, $\delta$, ppm $(J, \mathrm{~Hz}): 1.21$ (d, 3H, $\left.J=6.2,-\mathrm{CH}_{3}\right), 3.18,3.74$ (dd, $\left.1 \mathrm{H}, J=2.3, J=7.5, \mathrm{t}, 1 \mathrm{H}, J=9.7,-\mathrm{CH}_{2}-\right) ; 4.05(\mathrm{~m}, 1 \mathrm{H}$, $\left.-\mathrm{CHCH}_{3}\right), 7.29\left(\mathrm{~b}, 2 \mathrm{H},-\mathrm{NH}_{2}, \mathrm{D}_{2} \mathrm{O}\right.$ exchangeable), and 9.13 (b, $2 \mathrm{H},-\mathrm{NH}-, \mathrm{D}_{2} \mathrm{O}$ exchangeable). ${ }^{13} \mathrm{C}$ NMR, $\delta$, ppm: 20.4 $\left(-\mathrm{CH}_{3}\right), 50.2\left(-\mathrm{CH}_{2}-\right), 51.2\left(-\mathrm{CHCH}_{3}\right), 63.0(\mathrm{~N} \equiv \mathrm{C}-\mathrm{C}=\mathrm{C}-)$, $118.9(-\mathrm{C} \equiv \mathrm{N}), 164.3(\mathrm{~N} \equiv \mathrm{C}-\mathrm{C}=\mathrm{C}-)$, and $188.7(-\mathrm{C}=\mathrm{S})$. Anal. Calcd. for $\mathrm{C}_{7} \mathrm{H}_{10} \mathrm{~N}_{4} \mathrm{~S}$ (182) C 46.13; H 5.53; N 30.74; S 17.59\%, Found: C 46.08; H 5.61; N 30.81; S 17.50.

2-Cyano-2-(octahydro-2H-benzo[d]imidazol-2-ylidene)ethanethioamide $4 \boldsymbol{c}$. Brown needles, $\mathrm{mp} 238-240^{\circ} \mathrm{C}$; FT-IR, $v$, $\mathrm{cm}^{-1}$ : 3418 (broad, medium, $-\mathrm{NH}_{2}$ ), 3273 (broad, medium, $-\mathrm{NH}-$ ), 2187 (strong, sharp, $-\mathrm{C} \equiv \mathrm{N}$ ), and 1589 (strong, sharp, $-\mathrm{C}=\mathrm{C}) ;{ }^{1} \mathrm{H}$ NMR, $\delta, \operatorname{ppm}(J, \mathrm{~Hz}): 1.28-1.56$ (m, 
$\left.4 \mathrm{H},-\mathrm{CHCH}_{2} \mathrm{CH}_{2}-\right), 1.64-1.74,2.12(\mathrm{~m}, 2 \mathrm{H}, \mathrm{d}, 2 \mathrm{H}, J=$ 11.0, $-\mathrm{CHCH}_{2} \mathrm{CH}_{2}-$ ), 3.07, 3.82 (m, $\left.1 \mathrm{H}, \mathrm{m}, 1 \mathrm{H},-\mathrm{NHCH}-\right)$, $7.63\left(\mathrm{~b}, 2 \mathrm{H},-\mathrm{NH}_{2}, \mathrm{D}_{2} \mathrm{O}\right.$ exchangeable, $54.0(\mathrm{NHCH}), 62.5$ $(\mathrm{N} \equiv \mathrm{C}-\mathrm{C}=\mathrm{C}-), 118.5(-\mathrm{C} \equiv \mathrm{N}), 165.2(\mathrm{~N} \equiv \mathrm{C}-\mathrm{C}=\mathrm{C}-)$, and 189.0 (-C=S). Anal. Calcd. for $\mathrm{C}_{10} \mathrm{H}_{14} \mathrm{~N}_{4} \mathrm{~S}$ (222) C 54.03; $\mathrm{H} 6.35 ; \mathrm{N}$ 25.20; S 14.42\%, Found: C 54.10; H 6.44; N 25.12; S 14.34.

\section{Conclusion}

In summary, several new imidazolidines and tetrahydropyrimidines have been synthesized from the reaction of a single thioamide with several various diaminoalkanes. On the basis of our previously reported work [21], the thioamide itself was synthesized in a regioselective manner from functionalized oxazolidine with phosphorus pentasulfide.

\section{Conflict of Interests}

The authors declare that there is no conflict of interests regarding the publication of this paper.

\section{Acknowledgment}

The authors would like to thank Mrs. Marzieh Akbari for recording spectral NMR analyses.

\section{References}

[1] J. Chang-Fong, K. Benamour, B. Szymonski, F. Thomasson, J. Morand, and M. Cussac, "Synthesis and $\alpha$-adrenergic binding ligand affinities of 2-iminoimidazolidine derivatives," Chemical and Pharmaceutical Bulletin, vol. 48, no. 5, pp. 729-733, 2000.

[2] S. S. Szinai, G. Crank, and D. R. K. Harding, "Perfluoroalkyl carbonyl compounds. 1. Perfluoroaldehyde and perfluorocarboxylic acid derivatives," Journal of Medicinal Chemistry, vol. 13, no. 6, pp. 1212-1215, 1970.

[3] J. Saczewski, A. L. Hudson, and A. Rybczyńska, "2[(arylmethoxy)imino]imidazolidines with potential biological activities," Acta Poloniae Pharmaceutica-Drug Research, vol. 66, no. 6, pp. 671-680, 2009.

[4] M. C. Caterina, I. A. Perillo, L. Boiani et al., "Imidazolidines as new anti-Trypanosoma cruzi agents: biological evaluation and structure-activity relationships," Bioorganic and Medicinal Chemistry, vol. 16, no. 5, pp. 2226-2234, 2008.

[5] J. K. D. A. L. Neves, S. P. S. Botelho, C. M. L. de Melo et al., "Biological and immunological activity of new imidazolidines against adult worms of Schistosoma mansoni," Parasitology Research, vol. 107, no. 3, pp. 531-538, 2010.

[6] F. Marki, O. Buch, and A. Delini-Stula, "Sulfonyliminoimidazolidines, a new class of oral hypoglycemic agents. 4. Toxicity and general pharmacology of 1-p-[2-(crotonylamino)-ethyl]phenylsulfonyl-3-cyclohexyl-1-2-imino-imi dazolidine (CGP 11 112)," Arzneimittel-Forschung, vol. 34, no. 3, pp. 247-252, 1984.

[7] J. A. de Sousa Luis, J. M. B. Filho, B. F. Lira et al., "Synthesis of new imidazolidin-2,4-dione and 2-thioxoimidazolidin-4-ones viaC-phenylglycine derivatives," Molecules, vol. 15, no. 1, pp. 128-137, 2010.

[8] M. H. Rossi and R. Zelnik, "Contribution to the chemistry of imidazolidinediones-synthesis of ciclanylidene-hydantoins," Arquivos do Instituto Biológico, vol. 67, no. 1, pp. 125-130, 2000.
[9] M. S. Y. Khan and G. Chawla, “Tetrahydroimidazoles: a promising group of expected NSAIDS-their synthesis and antiinflammatory activity," Indian Journal of Chemistry B: Organic and Medicinal Chemistry, vol. 41, no. 3, pp. 653-663, 2002.

[10] V. Sharma and M. S. Y. Khan, "Synthesis of novel tetrahydroimidazole derivatives and studies for their biological properties," European Journal of Medicinal Chemistry, vol. 36, no. 7-8, pp. 651-658, 2001.

[11] M. V. Patel, R. Bell, S. Majest, R. Henry, and T. Kolasa, "Synthesis of 4,5-Diaryl- $1 H$-pyrazole-3-ol derivatives as potential COX-2 inhibitors," The Journal of Organic Chemistry, vol. 69, no. 21, pp. 7058-7065, 2004.

[12] M. D. Mashkovskii, Medicinals, Part 1, p. 736, Part 2, p. 688, Meditsina, Moscow, Russia, 1993, (Russian).

[13] N. B. Nikolaeva, Ed., Medicinal Products from Foreign Firms in Russia (in Russian), Astrafarmservis, Moscow, Russia, 1993.

[14] S. N. Mokale, S. S. Shinde, R. D. Elgire, J. N. Sangshetti, and D. B. Shinde, "Synthesis and anti-inflammatory activity of some 3-(4,6-disubtituted-2-thioxo-1,2,3,4-tetrahydropyrimidin-5-yl) propanoic acid derivatives," Bioorganic \& Medicinal Chemistry Letters, vol. 20, no. 15, pp. 4424-4426, 2010.

[15] N. Arora and S. N. Pandeya, "Synthesis and analgesic activity of novel pyrimidine derivatives," International Journal of Pharmaceutical Sciences Review and Research, vol. 11, no. 1, pp. 48-52, 2011.

[16] J. Yuan, X. Cai, D. Chen, and M. Hu, "Synthesis, structure analysis, and antitumor activity of (R)-2,4-dioxo-5-fluoro1-[1-(methoxycarbonyl) ethylaminocarbonylmethyl]-1,2,3,4tetrahydropyrimidine," Chinese Journal of Chemistry, vol. 25, no. 3, pp. 417-421, 2007.

[17] K. Weinhardt, M. B. Wallach, and M. Marx, "Synthesis and antidepressant profiles of phenyl-substituted 2-amino- and 2[(alkoxycarbonyl)amino]-1,4,5,6-tetrahydropyrimidines," Journal of Medicinal Chemistry, vol. 28, no. 6, pp. 694-698, 1985.

[18] H. R. Champaneri, S. R. Modi, and H. B. Naik, "Studies on pyrimidines, part II: synthesis and antibacterial activity of 7-(2'-hydroxy-5'-methylphen-1'yl)-2-aceyl-5-substituted phenyl-3-oxo-2,3,4,4-tetrahydeothiazolo (3,2-a)-pyrimidines," Asian Journal of Chemistry, vol. 6, no. 3, pp. 737-738, 1994.

[19] K. Satyavathi, T. Naga Ravi Kiran, P. Bhoja Raju, and M. Sharmila, "Synthesis and screening of 3-formyl-2-thio-1,2,3,4tetrahydro pyrimidine analogues as antibacterial agents," Asian Journal of Chemistry, vol. 22, no. 7, pp. 5182-5186, 2010.

[20] T. N. Akhaja and J. P. Raval, "Design, synthesis, in vitro evaluation of tetrahydropyrimidine-isatin hybrids as potential antibacterial, antifungal and anti-tubercular agents," Chinese Chemical Letters, vol. 23, no. 4, pp. 446-449, 2012.

[21] M. Bakavoli, H. Beyzaei, M. Rahimizadeh, and H. Eshghi, "Regioselective synthesis of new 2-(E)-cyano(oxazolidin-2ylidene)thiazoles," European Journal of Chemistry, vol. 2, no. 3, pp. 356-358, 2011. 

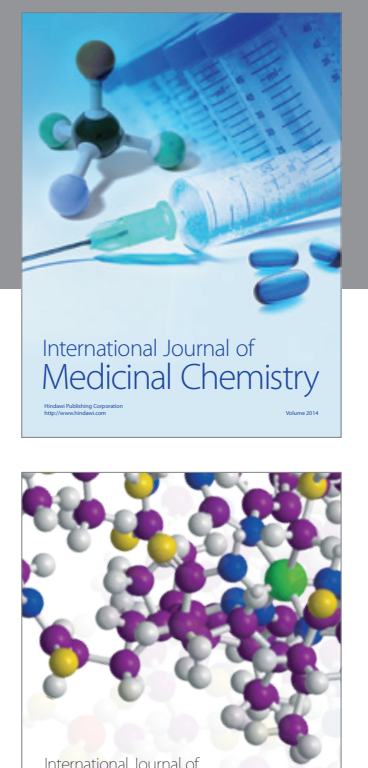

\section{Carbohydrate} Chemistry

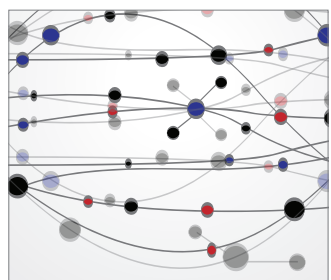

The Scientific World Journal
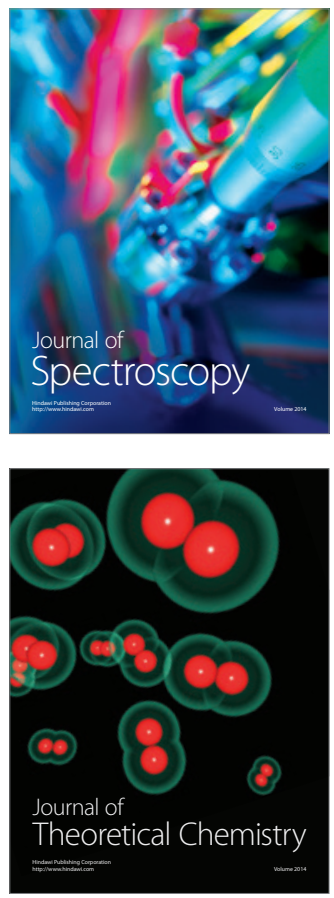
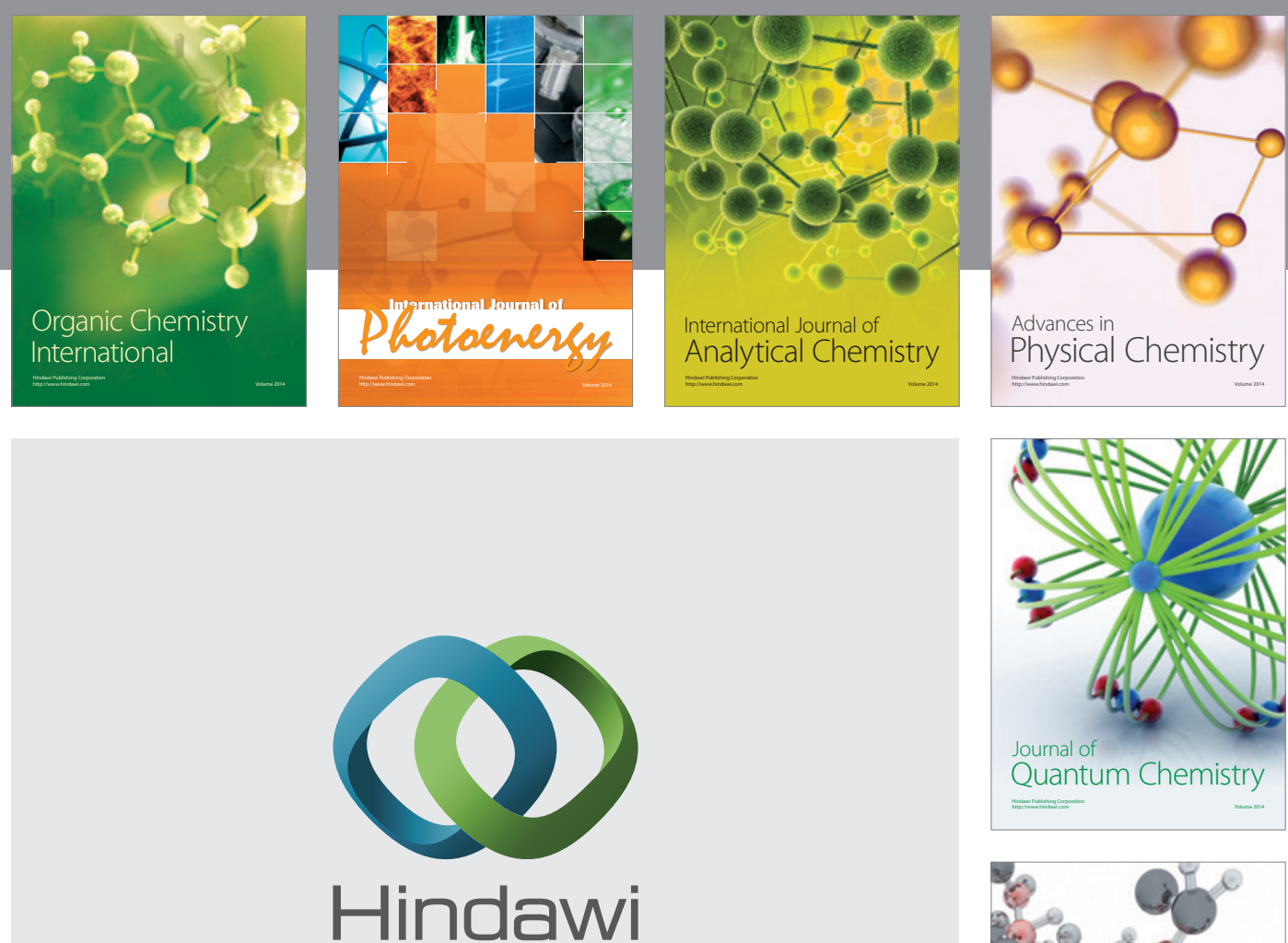

Submit your manuscripts at

http://www.hindawi.com

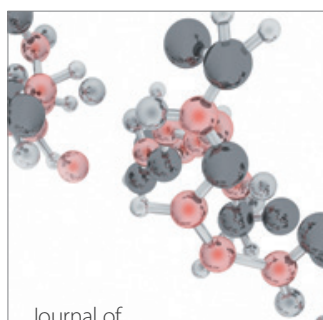

Analytical Methods

in Chemistry

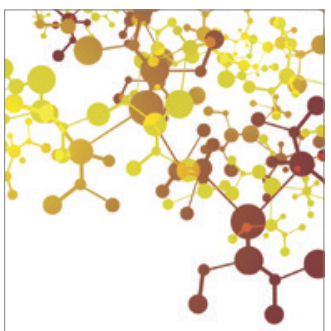

Journal of

Applied Chemistry

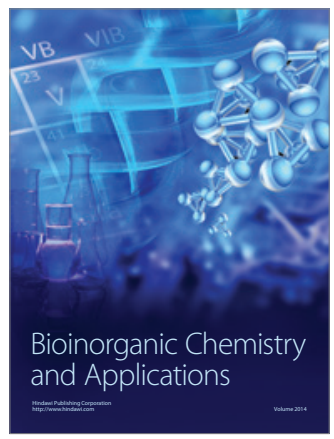

Inorganic Chemistry
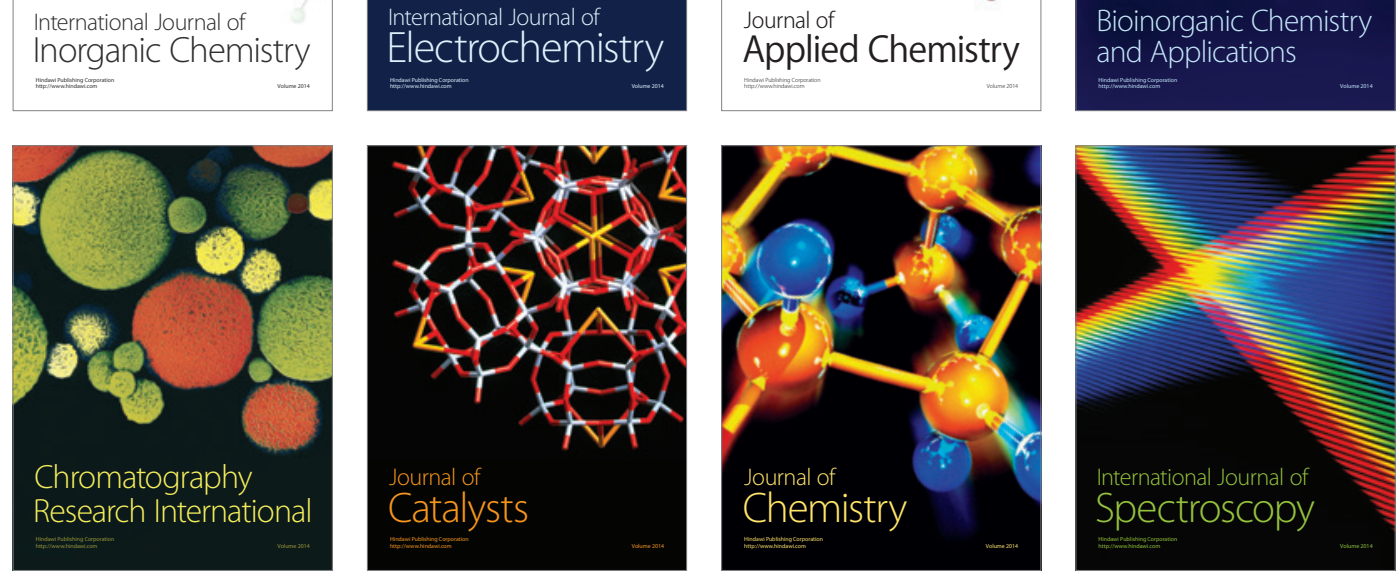